\title{
Development and validation of PCR-based assays for diagnosis of American cutaneous leishmaniasis and identification of the parasite species
}

\author{
Grazielle Cardoso da Graça ${ }^{1}$, Angela Cristina Volpini ${ }^{1,2}$, Gustavo Adolfo Sierra Romero³, \\ Manoel Paes de Oliveira Neto ${ }^{4}$, Marcia Hueb ${ }^{5}$, Renato Porrozzi ${ }^{1}$, \\ Mariana Côrtes Boité1, Elisa Cupolillo'/+
}

\author{
1'Laboratório de Pesquisa em Leishmaniose, Coleção de Leishmania, Instituto Oswaldo Cruz \\ ${ }^{4}$ Instituto de Pesquisa Clínica Evandro Chagas-Fiocruz, Rio de Janeiro, RJ, Brasil ${ }^{2}$ Grupo de Genômica e Biologia Computacional, \\ Instituto René Rachou-Fiocruz, Belo Horizonte, MG, Brasil ${ }^{3}$ Laboratório de Leishmanioses, Núcleo de Medicina Tropical, \\ Universidade de Brasília, Brasília, DF, Brasil ${ }^{5}$ Faculdade de Medicina, Universidade Federal de Mato Grosso, Cuiabá, MT, Brasil
}

\begin{abstract}
In this study, PCR assays targeting different Leishmania heat-shock protein 70 gene (hsp70) regions, producing fragments ranging in size from 230-390 bp were developed and evaluated to determine their potential as a tool for the specific molecular diagnosis of cutaneous leishmaniasis (CL). A total of 70 Leishmania strains were analysed, including seven reference strains (RS) and 63 previously typed strains. Analysis of the RS indicated a specific region of $234 \mathrm{bp}$ in the hsp70 gene as a valid target that was highly sensitive for detection of Leishmania species DNA with capacity of distinguishing all analyzed species, after polymerase chain reaction-restriction fragment length polymorfism (PCR-RFLP). This PCR assay was compared with other PCR targets used for the molecular diagnosis of leishmaniasis: hsp70 (1400-bp region), internal transcribed spacer (ITS)1 and glucose-6-phosphate dehydrogenase (G6pd). A good agreement among the methods was observed concerning the Leishmania species identification. Moreover, to evaluate the potential for molecular diagnosis, we compared the PCR targets hsp70-234 bp, ITS1, G6pd and mkDNA using a panel of 99 DNA samples from tissue fragments collected from patients with confirmed CL. Both PCR-hsp70-234 bp and PCR-ITS1 detected Leishmania DNA in more than 70\% of the samples. However, using hsp70-234 bp PCR-RFLP, identification of all of the Leishmania species associated with CL in Brazil can be achieved employing a simpler and cheaper electrophoresis protocol.
\end{abstract}

Key words: leishmaniasis - molecular diagnosis - species identification - polymerase chain reaction - RFLPs - $h s p 70$

Leishmaniasis are parasitic diseases caused by a heteroxenous protozoan of the genus Leishmania (Ross 1903). Leishmaniasis are complex diseases showing significant clinical pleomorphism and epidemiological diversity. The genus Leishmania is comprised of approximately 30 species, approximately 20 of which are pathogenic for humans (Desjeux 2004).

Definitive diagnosis of cutaneous leishmaniasis (CL) can be challenging, especially in endemic areas where other diseases with similar clinical symptoms occur. The currently accepted gold standard for diagnosis requires isolation of the parasites involved and microscopic visualisation of amastigotes in tissue fragments from a lesion, though identification of the etiological agent at the species level is only possible if the parasite is suc-

Financial support: FIOCRUZ, FAPERJ, CNPq (MCT/CNPq/CTSaúde/MS/SCTIE/DECIT 34/2008 - Doenças Negligenciadas 576104/2008-6), Edital Pró-Equipamentos CAPES (27/2010), European Union (LeishEpinetSA, INCO-CT2005-015407)

$\mathrm{GC}$ da $\mathrm{G}$ and ACV contributed equally to this work.

+Corresponding author: ecupoli@ioc.fiocruz.br

Received 31 October 2011

Accepted 2 April 2012 cessfully cultured (Herwaldt 1999, Desjeux et al. 2004, Reithinger et al. 2007).

The identification of Leishmania species in infected patients is crucial for achieving a correct prognosis and diagnosis (Arévalo et al. 2007). However, because of morphological similarities among the species of this genus, common parasitological assessments cannot discriminate between them (Weigle et al. 1986, Wilson et al. 1995, Aviles et al. 1999, Romero et al. 2001). Similarly, immunological tests, though useful for diagnosis, do not allow discrimination between Leishmania species.

Multilocus enzyme electrophoresis (MLEE) (Rioux et al. 1990), which is the gold standard for the identification of Leishmania species, requires prior isolation and mass culturing of the parasites. However, isolation can be complicated by the occurrence of secondary infections and the protocol is costly and time consuming. Therefore, a method that ensures the direct diagnosis and identification of pathogenic Leishmania species is still required for an appropriate therapy to be developed, as well as to contribute to epidemiological studies.

The diversity of the species associated with human $\mathrm{CL}$ in Brazil further necessitates the development of a method for the diagnosis of CL and determination of pathogenic Leishmania species. In Brazil, there are two attributes of Leishmania braziliensis that warrant particular attention: (i) the species is widely distributed and 
is often the sole or primary etiological agent of $\mathrm{CL}$ in several endemic areas and (ii) it is associated with the mucocutaneous form of the disease. However, this situation regarding Leishmania species is not static, as a few studies have revealed the presence of some species in areas where they had not previously been recorded (Azeredo-Coutinho et al. 2007, Azpurua et al. 2010, van Thiel et al. 2010), and other pathogenic species, such as Leishmania guyanensis, have been demonstrated to play an important role in the epidemiology of mucocutaneous leishmaniasis (Guerra et al. 2011).

Developing suitable detection methods for Leishmania infections that also distinguish between the pathogenic species involved has been a major challenge. Polymerase chain reaction (PCR)-based methods involving different targets have been proposed to enable characterisation at the species level; these protocols have been tested in Leishmania promastigotes and for direct detection of the parasites in infected human or other animal tissues, including phlebotomine sandflies [see Reithinger and Dujardin (2007), Goto and Lindoso (2010), Schönian et al. (2011) for more details].

Whereas PCR assays targeted at amplification of internal transcribed spacer (ITS)1-rDNA are among the most commonly used methods for the diagnosis and identification of Leishmania species in the Old World (Schönian et al. 2010a), PCR targeted at amplification of the conserved locus of kDNA minicircles (mkDNA) has been widely used in Brazil (Ampuero et al. 2009). Digestion of the ITS1 amplicon using the restriction enzyme HaeIII has been demonstrated to be able to distinguish between nearly all Leishmania species, although distinction of some species, such as L. braziliensis and L. guyanensis, is only possible via sequence analysis of this region (Schönian et al. 2003). Few methods have been developed for the identification of specific species; one such protocol employs a PCR protocol that targets amplification of the glucose-6-phosphate dehydrogenase $(G 6 p d)$ gene of L. braziliensis, which is the main etiological agent of mucocutaneous leishmaniasis in the Americas (Castilho et al. 2003).

A PCR-restriction fragment length polymorfism (RFLP) assay for the heat-shock protein 70 gene $(h s p 70)$ has recently been presented as a simple, universal tool for discrimination of Leishmania species in both the New and Old Worlds (Montalvo et al. 2010). This tool has been successfully used to distinguish human pathogenic Leishmania species circulating in Brazil (da Silva et al. 2010). Although this technique has already been used for direct diagnosis of CL (Garcia et al. 2004), the sensitivity of this assay is compromised by the large size (1400-bp) of the target region. Therefore, in this study, a region of the hsp 70 gene of Leishmania spp was analysed and primers flanking regions ranging from 234-384 bp in length were designed for amplification of smaller fragments of this gene. The ability of these regions to distinguish between Leishmania species was assessed by digesting each PCR product with restriction enzymes. A panel of 70 strains (including reference strains) of the Leishmania species circulating in Brazil was used for this purpose. In addition, the feasibility of this method was evaluated, including comparison with other PCR-based assays for the molecular diagnosis of CL using a panel of clinical samples from several endemic areas in Brazil.

\section{SUBJECTS, MATERIALS AND METHODS}

Leishmania strains - References strains of $L$. braziliensis, L. guyanensis, Leishmania naiffi, Leishmania shawi, Leishmania lainsoni, Leishmania amazonensis and Leishmania infantum, in addition to 63 other strains representative of these species, were used in this study (n $=70$ ) (Table I). The stocks were frozen in liquid nitrogen and are part of the archive of the Leishmania Collection at the Oswaldo Cruz Institute (CLIOC); all of the strains were previously identified using MLEE. After thawing, the parasites were cultured in a two-phase culture medium (NNN-Schneider) (Cupolillo et al. 1994). DNA from these strains was extracted using the Wizard ${ }^{\mathrm{TM}}$ Genomic DNA Purification kit (Promega, WI, USA) according to the manufacturer's instructions. The extracted DNA was quantified using a Nanodrop ${ }^{\circledR}$ spectrophotometer.

Clinical samples - A total of 99 DNA samples from tissue fragments collected from patients with a confirmed diagnosis of CL were used in this study. Biopsies were performed by physicians as part of the routine procedure for the diagnosis of leishmaniasis, according to ethical protocols, including obtaining patient consent and approval from the respective ethics committees. A total of 50, 29 and 20 samples were used from patients who resided in the states of Acre (AC), Rio de Janeiro (RJ) and Mato Grosso, respectively (Table II).

The biopsies were frozen and stored at $-20^{\circ} \mathrm{C}$ prior to DNA extraction using the Wizard ${ }^{\mathrm{TM}}$ Genomic DNA Purification kit according to the manufacturer's instructions, which included a prior phase of digestion with proteinase $\mathrm{K}$.

PCR and RFLP assays - New primers were designed for amplification of smaller fragments corresponding to regions of the $h s p 70$ gene (Fig. 1, Table III). Primer design was accomplished via analysis of sequences from the Leishmania hsp70 gene [which were deposited in GenBank (GU071172.1 - GU071188.1)] using the PrimerBlast tool available from the National Center for Biotechnology Information. Seven primers were designed (forward: $h s p 70 \mathrm{~F} 1, h s p 70 \mathrm{~F} 2, h s p 70 \mathrm{~F} 3$ and $h s p 70 \mathrm{~F} 4$; reverse: $h s p 70 \mathrm{R} 1, h s p 70 \mathrm{R} 2$ and $h s p 70 \mathrm{R} 3)$ and combined to amplify four different fragments: $h s p 70 \mathrm{~A}(230 \mathrm{bp}), h s p 70 \mathrm{~B}$ (384 bp), hsp70C (234 bp) and hsp70D (379 bp) (Fig. 1, Table III). These regions were selected based on the inter-species polymorphisms. The PCR amplifications were performed in a final volume of $25 \mu \mathrm{L}$ containing $1 \mu \mathrm{L}$ of DNA, 20 pmol of each primer, $200 \mu \mathrm{M}$ dNTPs, $1.5 \mathrm{mM} \mathrm{MgCl} 2$ and $1 \mathrm{U} \mathrm{GoTaq}^{\circledR}$ DNA polymerase (M3005, Promega). The PCR assays used the following amplification cycle: $94^{\circ} \mathrm{C}$ for $5 \mathrm{~min}$ followed by 30 cycles of $94^{\circ} \mathrm{C}$ for $30 \mathrm{sec}, 61^{\circ} \mathrm{C}$ for $1 \mathrm{~min}$ and $72^{\circ} \mathrm{C}$ for 3 min and a final extension at $72^{\circ} \mathrm{C}$ for $8 \mathrm{~min}$.

PCR assays targeting different genomic DNA regions were performed using DNA extracted from promastigotes of the Leishmania strains (Table I) employing the following, previously described, methods: (i) PCR amplification of the G6pd gene locus (PCR-G6pd) us- 


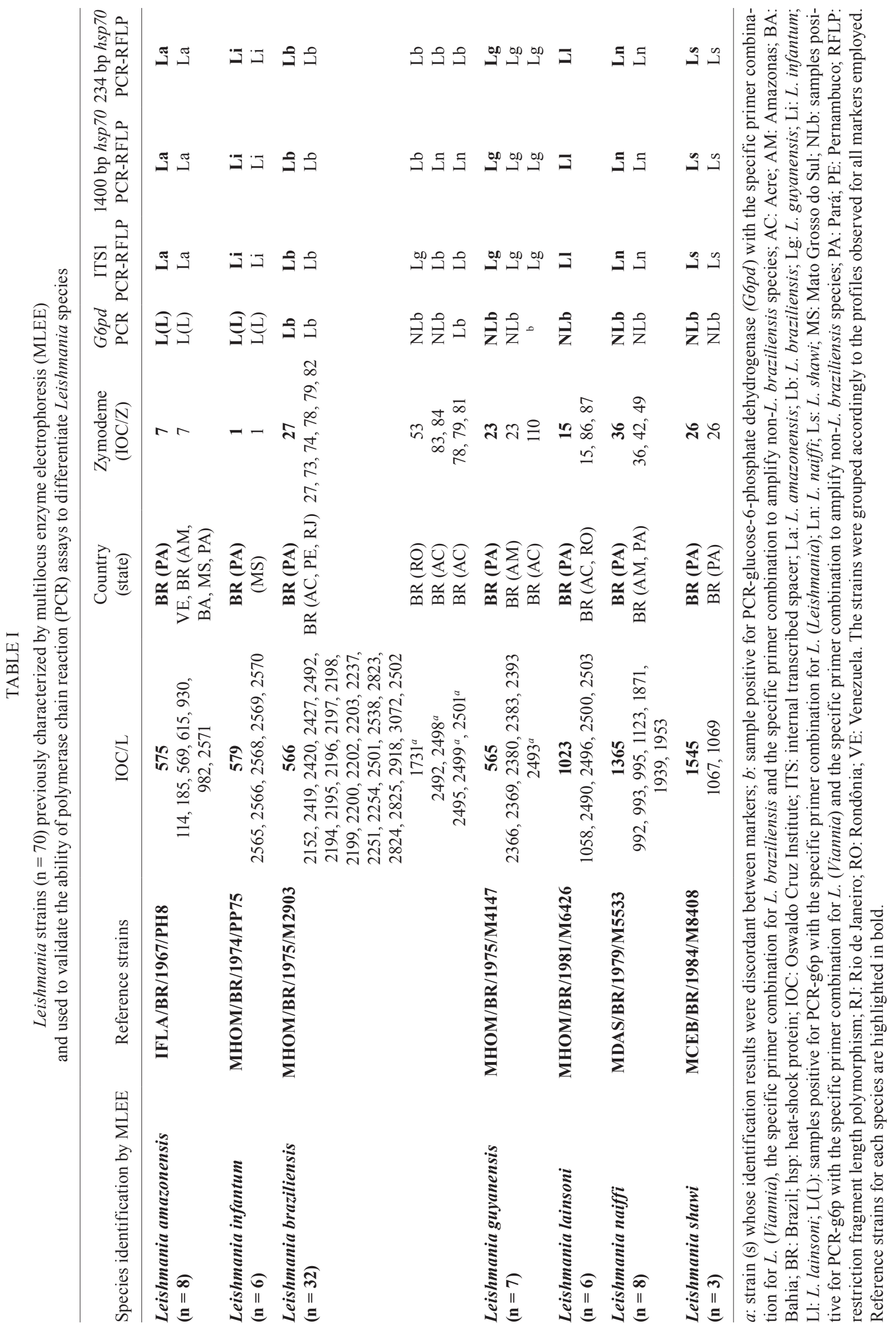


ing a combination of primers (Castilho et al. 2003, Tojal da Silva et al. 2006); (ii) PCR targeting the ITS1 rDNA gene (PCR-ITS1) (Schönian et al. 2003, Tojal da Silva et al. 2006), (iii) PCR targeting a 1400-bp fragment of the hsp70 gene from Leishmania (PCR-hsp70) (Garcia et al. 2004, da Silva et al. 2010) and (iv) PCR targeting a 234bp region of the $h s p 70$ gene (see above for details).

Four PCR protocols were applied to DNA extracted from tissue fragments collected from lesions of patients who were diagnosed with CL. PCR targeting the conserved region of the mkDNA (120-bp PCR-mkDNA) (Volpini et al. 2004) was used only for molecular diagnostics and not for species identification. PCR-G6pd, PCR-ITS1 and 234bp PCR- $h s p 70$ were used as described above.

The PCR products obtained from the different assays were visualised after electrophoresis on a $6 \%$ polyacrylamide gel, either by silver staining using a specific kit (DNA Silver Staining, GE Healthcare, 176000-30) or with ultraviolet light after being stained with ethidium bromide.

TABLE II

Detection and identification of Leishmania spp by different polymerase chain reaction (PCR)-based methods using DNA extracted from 99 tissue samples collected from lesions of patients with clinical diagnosis of leishmaniasis

\begin{tabular}{|c|c|c|c|c|c|c|c|c|c|c|}
\hline Profile & Kdna & ITS1 & $\begin{array}{c}\text { ITS1 } \\
\text { PCR-RFLP }\end{array}$ & $\begin{array}{c}234 \mathrm{bp} \\
h s p 70\end{array}$ & $\begin{array}{l}234 \text { bp hsp70 } \\
\text { PCR-RFLP }\end{array}$ & $\begin{array}{l}G 6 p d^{a} \\
{[\mathrm{~L}(\mathrm{~V})]}\end{array}$ & $\begin{array}{l}G 6 p d^{a} \\
(\mathrm{Lb})\end{array}$ & $\begin{array}{c}G 6 p \mathrm{~d}^{a} \\
\text { (non-Lb) }\end{array}$ & $\mathrm{n}^{b}$ & Geographic origin \\
\hline 1 & + & + & $\mathrm{Lb}$ & + & $\mathrm{Lb}$ & + & + & - & 10 & $\mathrm{AC}, \mathrm{RJ}$ \\
\hline 2 & + & + & $\mathrm{Lb}$ & + & $\mathrm{Lb}$ & - & + & - & 2 & $\mathrm{AC}$ \\
\hline 3 & + & + & $\mathbf{L b}$ & + & Ln & + & + & - & 2 & $\mathrm{AC}$ \\
\hline 4 & + & + & Lg & + & Lg & + & + & + & 1 & $\mathrm{AC}$ \\
\hline 5 & + & + & $\mathbf{L g}$ & + & $\mathbf{L g}$ & + & + & - & 1 & $\mathbf{A C}$ \\
\hline 6 & + & + & Ls & + & Ls & NP & NP & NP & 1 & MT \\
\hline 7 & + & + & $\mathrm{Lb}$ & - & - & NP & NP & NP & 3 & MT \\
\hline 8 & + & + & $\mathrm{Lb}$ & + & $\mathrm{Lb}$ & - & - & - & 15 & $\mathrm{AC}, \mathrm{RJ}$ \\
\hline 9 & + & + & $\mathrm{Lb}$ & + & $\mathrm{Lb}$ & + & - & - & 1 & $\mathrm{AC}$ \\
\hline 10 & + & + & $\mathrm{Lb}$ & + & $\mathrm{Lb}$ & NP & NP & NP & 11 & MT \\
\hline 11 & + & + & $\mathrm{La}$ & + & $\mathrm{La}$ & NP & NP & NP & 1 & MT \\
\hline 12 & + & + & $\mathbf{L n} / \mathbf{L l}$ & + & Ll & - & - & + & 1 & $\mathbf{A C}$ \\
\hline 13 & + & + & $\mathrm{Ll}$ & + & $\mathrm{Ll}$ & + & - & - & 1 & $\mathrm{AC}$ \\
\hline 14 & + & + & $\mathrm{Ll}$ & + & $\mathrm{Ll}$ & - & - & - & 5 & $\mathrm{AC}$ \\
\hline 15 & + & + & $\mathrm{Ll}$ & + & $\mathrm{Ll}$ & - & - & + & 4 & $\mathrm{AC}$ \\
\hline 16 & + & + & $\mathrm{Ll}$ & + & $\mathrm{Ll}$ & NP & NP & NP & 1 & MT \\
\hline 17 & + & + & $\mathrm{Ll}$ & - & - & - & & - & 2 & $\mathrm{AC}$ \\
\hline 18 & + & + & $\mathrm{Ln}$ & + & $\mathrm{Ln}$ & - & - & - & 2 & $\mathrm{AC}$ \\
\hline 19 & + & + & $\mathrm{Ln}$ & + & Ln & + & - & + & 1 & $\mathrm{RJ}$ \\
\hline 20 & + & + & Ln & + & $\mathbf{L b}$ & + & - & - & 1 & $\mathbf{A C}$ \\
\hline 21 & + & + & $\mathrm{Lb}$ & - & - & + & + & - & 5 & $\mathrm{AC}, \mathrm{RJ}$ \\
\hline 22 & + & + & $\mathrm{Lb}$ & - & - & - & - & - & 5 & $\mathrm{AC}, \mathrm{RJ}$ \\
\hline 23 & + & + & $\mathrm{Lb}$ & - & - & NP & NP & NP & 3 & MT \\
\hline 24 & + & - & - & + & $\mathrm{Ll}$ & + & - & - & 1 & $\mathrm{AC}$ \\
\hline 25 & + & - & - & - & - & - & - & - & 1 & $\mathrm{AC}$ \\
\hline 26 & + & - & - & + & $\mathrm{Lb}$ & + & + & - & 1 & $\mathrm{RJ}$ \\
\hline 27 & + & - & - & + & $\mathrm{Lb}$ & - & - & - & 8 & $\mathrm{AC}, \mathrm{RJ}$ \\
\hline 28 & + & - & - & - & - & + & + & - & 1 & $\mathrm{RJ}$ \\
\hline 29 & + & - & - & - & - & - & - & - & 6 & $\mathrm{AC}, \mathrm{RJ}$ \\
\hline 30 & - & + & $\mathrm{Lb}$ & - & - & - & - & - & 1 & $\mathrm{RJ}$ \\
\hline 31 & - & + & $\mathrm{Lb}$ & + & $\mathrm{Lb}$ & - & - & - & 1 & $\mathrm{RJ}$ \\
\hline Total & 97 & 81 & - & 72 & - & 26 & 24 & 7 & 99 & - \\
\hline
\end{tabular}

$a$ : see Subjects, Materials and Methods for details; $b$ : total of samples presenting this result; AC: Acre; hsp: heat-shock protein; ITS: internal transcribed spacer; La: Leishmania amazonensis; Lb: Leishmania braziliensis; Lg: Leishmania guyanensis; Ll: Leishmania lainsoni; Ln: Leishmania naiffi; Ls: Leishmania shawi; L(V): L. (Viannia); MT: Mato Grosso; NP: not performed; RFLP: restriction fragment length polymorphism; RJ: Rio de Janeiro; +: positive PCR; -: negative PCR. Samples presenting discordant species identification results were highlighted in bold. 
The PCR products from the amplification of ITS1 and hsp70 (1400 bp or smaller) were subjected to digestion with restriction enzymes. For G6pd-PCR, a combination of subgenus or species-specific primers was used for identification of strains according to previously described protocols (Castilho et al. 2003, Tojal da Silva et al. 2006). The objective was to identify the subgenus and if the subgenus was $L$. (Viannia), to identify L. braziliensis.

The restriction enzyme Sau3AI was used for digestion of the ITS1 product based on previous results from our group (unpublished observations). HaeIII, MboI and $B s t \mathrm{UI}$ were used to digest the products of amplifications that targeted $h s p 70$ (da Silva et al. 2010). The amplification products for $h s p 70 \mathrm{~A}, h s p 70 \mathrm{~B}, h s p 70 \mathrm{C}$ and $h s p 70 \mathrm{D}$ from the reference strains were subjected to digestion with HaeIII, MboI, BccI, RsaI, AvaI, BstuI, KpnI and $S p h$ I. Based on the results obtained, only HaeIII and
$B s t u$ I were used to digest the products amplified (with hsp70C as the target) from DNA extracted from other samples. The digestion reactions with different restriction enzymes were performed according to the manufacturer's instructions. All of the enzymes used in this study were from New England BioLabs.

The obtained restriction products were electrophoresed on a $6 \%$ polyacrylamide gel, followed by silver staining using a specific kit, with the exception of ITS1, which was electrophoresed in a specific machine (GenePhor electrophoresis unit, GE Healthcare) using a highresolution gel (GeneGel Excel 12.5/24 kit, GE Healthcare) and the same silver-staining kit mentioned above.

Molecular identification of the Leishmania strains using DNA from promastigotes was performed as a blind assay, without prior knowledge of the identity determined via MLEE.

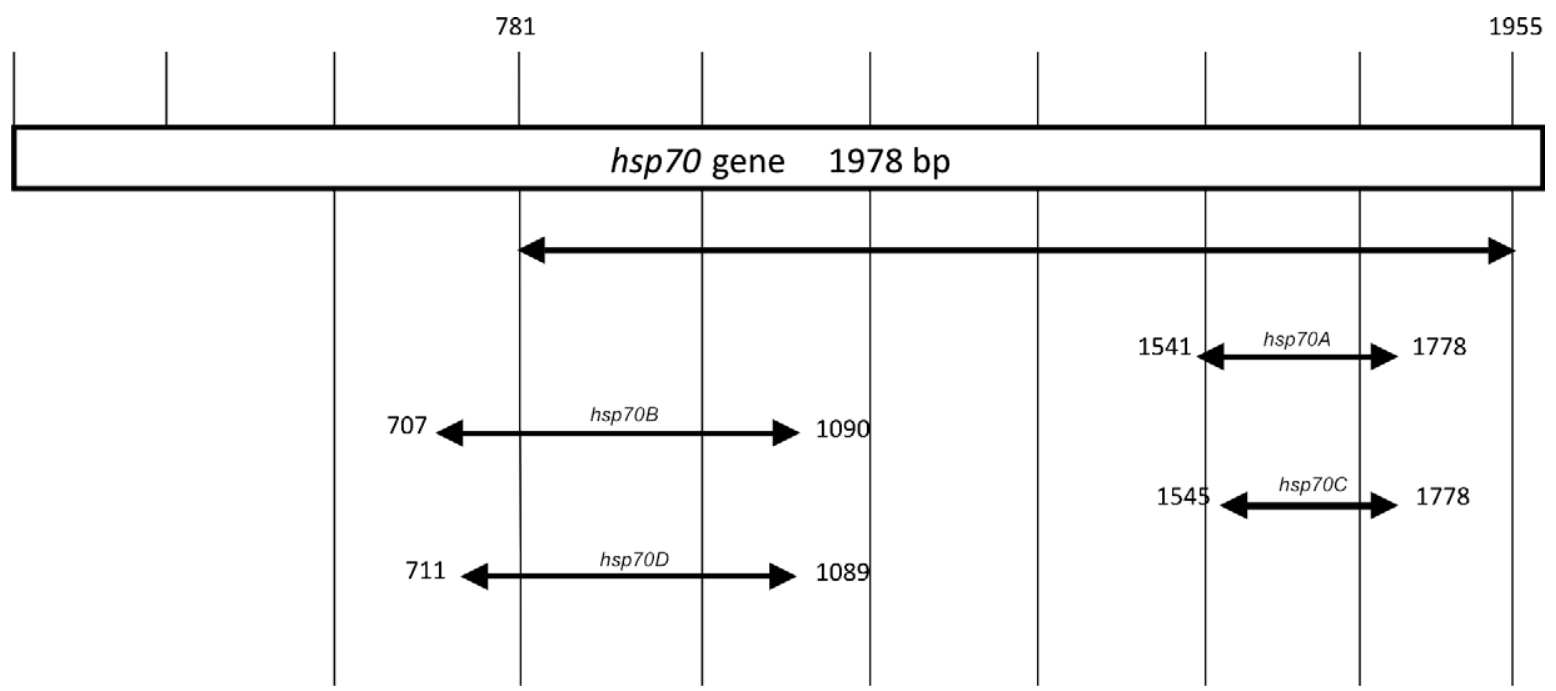

Fig. 1: position of polymerase chain reaction products from different primer combinations in relation to the heat-shock protein $(h s p) 70$ gene on chromosome 28 of Leishmania major [strain Friedlin (ncbi.nlm.nih.gov) accession FR796424 CT005266]. hsp70A: 230 bp; hsp70B: 384 bp; hsp70C: 234 bp; hsp70D: 379 bp.

TABLE III

Primers used for amplification of different regions of the $h s p 70$ gene

\begin{tabular}{|c|c|c|c|c|}
\hline PCR assay & Amplicon size & $\begin{array}{l}\text { Primer sequence } \\
\qquad\left(5^{\prime}>3^{\prime}\right)\end{array}$ & $\mathrm{Tm}$ & $\begin{array}{l}\mathrm{GC} \\
(\%)\end{array}$ \\
\hline hsp70A (230 bp hsp70) & $230 \mathrm{bp}$ & $\begin{array}{c}\text { GCAAGGACGAGATCGAGCGCA } \\
\text { TCCTTCGACGCCTCCTGGTTG }\end{array}$ & $\begin{array}{l}59.6 \\
58.2\end{array}$ & $\begin{array}{l}61.9 \\
61.9\end{array}$ \\
\hline$h s p 70 \mathrm{~B}(384 \mathrm{bp} h s p 70)$ & 384 bp & $\begin{array}{c}\text { ACAACCGCCTCGTCACGTTCT } \\
\text { TGTTCAGCTCCTTGCCGCCG }\end{array}$ & $\begin{array}{l}58.7 \\
59.9\end{array}$ & $\begin{array}{c}57.1 \\
65\end{array}$ \\
\hline hsp70C (234 bp hsp70) & 234 bp & $\begin{array}{c}\text { GGA CGAGATCGAGCGCATGGT } \\
\text { TCCTTCGACGCCTCCTGGTTG }\end{array}$ & $\begin{array}{l}59.7 \\
58.5\end{array}$ & $\begin{array}{l}61.9 \\
61.9\end{array}$ \\
\hline hsp70D (379 bp hsp70) & $379 \mathrm{bp}$ & $\begin{array}{c}\text { CCGCCTCGTCACGTTCTTCAGC } \\
\text { GTTCAGCTCCTTGCCGCCGA }\end{array}$ & $\begin{array}{l}60.3 \\
59.7\end{array}$ & $\begin{array}{c}63.6 \\
65\end{array}$ \\
\hline
\end{tabular}

GC: guanine-cytosine; hsp: heat-shock protein; PCR: polymerase chain reaction; Tm: melting temperature. 
A fragment of hamster tissue that was not infected with Leishmania was included as a negative control during the extraction of each clinical sample. A no DNA negative control was included in each PCR run.

As a positive control, a reaction containing DNA extracted from tissue fragments of a hamster that had been experimentally infected with $L$. amazonensis was included in each PCR run.

To avoid sample contamination, separate workstations were used to extract DNA from the promastigotes and clinical samples, to prepare the master mix solution for the addition of DNA to the master mix and to verify the amplicons via electrophoresis.

Sequencing - The products obtained for the hsp70C (234 bp) target from reference strains were visualised on a $2 \%$ agarose gel and purified using the Wizard SV Gel kit and PCR Clean-up System kit (Promega). The products were then sequenced with the same primers used for the PCR assay. Sequencing was performed on an automated sequencer (ABI PRISM ${ }^{\circledR}$ BigDye ${ }^{\mathrm{TM}}$ Terminator Cycle Sequencing) at the facilities of Oswaldo Cruz Foundation (IOC) (Genomic Platform - DNA sequencing, PDTIS-FIOCRUZ).

Statistical analysis - The number of positive clinical samples was calculated as a percentage using the results obtained for the different molecular markers evaluated in this study for detection of Leishmania DNA.

The Kappa index was used to determine the agreement between the results obtained for each molecular marker evaluated in the study (ITS1, G6pd and 234-bp hsp70). This calculation was performed using the software available at lee.dante.br/pesquisa/kappa/index.html.

The sensitivity of each method was determined based on comparison with the results of the PCR-mkDNA assay, which was considered as the gold standard because of its high sensitivity for CL diagnosis.

\section{RESULTS}

Identification of Leishmania spp reference strains PCR-RFLP of the ITS-1 product using Sau3AI differentiated between the analysed Leishmania species, although it was possible to distinguish between L. guyanensis and L. braziliensis only when electrophoresis of the digested product was performed on a high-resolution gel (Fig. 2).

PCR-RFLP of the 1400-bp hsp70 region differentiated between all of the species when Bst UI, MboI and HaelII were used, which supported the findings of previous studies (da Silva et al. 2010). The results could be visualised by electrophoresis using either a high-resolution gel or a $6 \%$ polyacrylamide gel (results not shown).

Neither PCR- $h s p 70 \mathrm{~B}$ nor PCR- $h s p 70 \mathrm{D}$ were useful for identification of the Leishmania species. The same profiles were observed for all of the species analysed, whether PCR-RFLP of the $h s p 70 \mathrm{~B}$ or the $h s p 70 \mathrm{D}$ targets was employed, with any of the restriction enzymes tested.

The assessment of the different $h s p 70$ fragments revealed that PCR-hsp 70C and PCR-hsp70A yielded identical results (i.e., the same RFLP profile), reflecting the fact that the primers for $h s p 70 \mathrm{~A}$ and $h s p 70 \mathrm{C}$ are targeted at flanking or neighbouring regions (Fig. 1). PCR-RFLP of either $h s p 70 \mathrm{~A}$ or $h s p 70 \mathrm{C}$ discriminated between all of the analysed Leishmania species when a maximum of three restriction enzymes (HaeIII, MboI and Bst UI) were used. HaeIII generated identical profiles for L. lainsoni and $L$. shawi as well as for $L$. braziliensis and $L$. naiffi, whereas L. guyanensis, L. amazonensis and L. infantum exhibited unique profiles. Bst $\mathrm{UI}$ differentiated $L$. naiffi from L. braziliensis and L. shawi from L. lainsoni; these species could also be differentiated using MboI (Fig. 3).

Because the same result was achieved via PCR-RFLP of either $h s p 70 \mathrm{~A}$ or C, the PCR $h s p 70 \mathrm{C}$ product (234 bp) for all of the reference strains was sequenced to determine whether it matched the expected region of the $h s p 70$ gene (Fig. 1). Sequence analysis revealed that this fragment corresponded to the region of the gene between base pairs $1545-1778$, which is a portion of the $h s p 70$ gene on chromosome 28 of Leishmania major [strain Friedlin (ncbi.nlm. nih.gov) accession FR796424 CT005266]. The sequences obtained were identical to a portion of the $h s p 70$ gene (region between sites 1346-1580) that was already deposited in GenBank for the same strains sequenced in the present study (L. naiffi: GU071183.1; L. shawi: GU071177.1; L. lainsoni: GU071174.1; L. braziliensis: GU071173.1; L. guyanensis: GU071172.1; L. amazonensis: EU599090.1), with polymorphisms observed between species.

Validation of species identification assays - All of the strains (Table I) were included in a blind assay to assess the reliability of the various targets for discriminating between Leishmania species.

The results of ITS1 PCR-RFLP validated the MLEE identification, with one exception. The PCR-RFLP profiles for the 1400-bp $h s p 70$ and 234-bp $h s p 70$ fragments from the different Leishmania species were repeated for the panel assembled with 63 strains and the identification obtained at the species level supported the MLEE results, although six exceptions were observed for the 1400-bp hsp70 PCR-RFLP (Table I).

Strain identification was also confirmed by the PCR-G6pd results, although this technique only discriminated between the subgenera L. (Leishmania) and L. (Viannia) and, within the latter, between L. braziliensis and non-L. braziliensis.
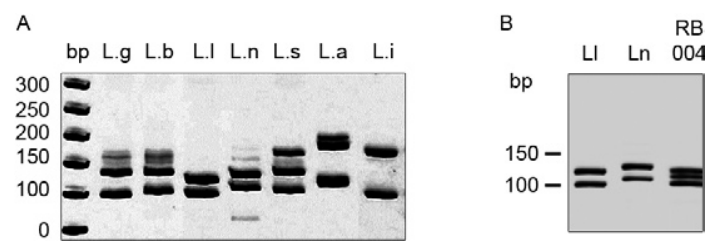

Fig. 2: internal transcribed spacer 1 polymerase chain reaction-restriction fragment length polymorphism profiles of different Leishmania species after digestion of products with Sau3AI. A: panel of profiles for reference strains; B: pattern for the sample RB004 from a patient diagnosed with cutaneous leishmaniasis, exhibiting a mixed profile between the species Leishmania lainsoni (L1) and Leismania naiffi $(\mathrm{Ln})$. Silver-stained $12.5 \%$ polyacrylamide gel $\left(\mathrm{Genephor}^{\circledR}\right)$. bp: 50 bp molecular weight marker; La: Leishmania amazonensis; Lb: Leishmania braziliensis; Lg: Leishmania guyanensis; Li: Leishmania infantum; Ls: Leishmania shawi. 
Discrepancies were only observed for seven strains (Table I). Strain IOC/L1731, which was characterised by MLEE as L. braziliensis, exhibited an L. guyanensis profile when ITS1 PCR-RFLP was used and a non- $L$. braziliensis profile when PCR-G6pd was used, although the 1400-bp $h s p 70$ and 234-bp hsp70C PCR-RFLP results validated the MLEE identification. Strains L2492 and L2498, which were characterised as L. braziliensis by MLEE and ITS1 PCR-RFLP, showed a non- $L$. braziliensis profile when PCR-G6pd was used and a $L$. naiffi profile when 1400-bp hsp70 PCR-RFLP was used. Strains L2495, L2499 and L2501, which were characterised as L. braziliensis by MLEE, ITS1 PCR-RFLP, PCRG6pd and 234-bp hsp70C PCR-RFLP, each presented an L. naiffi profile when 1400-bp hsp70 PCR-RFLP was used. Finally, strain L2493, which was characterised as L. guyanensis by MLEE and most of the molecular methods employed in this study, was positive in all of the G6pd PCR assays tested, meaning that it could not be identified as L. braziliensis or non-L. braziliensis.

Sensitivity of PCR methods for the diagnosis of leishmaniasis and the identification of Leishmania species in clinical samples - The DNA used in these assays was isolated from tissue fragments collected from cutaneous lesions of patients who had been diagnosed with CL based on clinical examination, parasitological analysis and/or their therapeutic response (Table II). High DNA concentrations can inhibit PCR and the DNA extracted from clinical samples can contain an amount of patient DNA that is much higher than the quantity of DNA from Leishmania; therefore, it is critical to determine the maximum DNA concentration to be used in each PCR assay. Although the effect of the concentration of human DNA on the PCR results was not evaluated in this study, quantities equal to or greater than $20 \mathrm{ng}$ hindered the amplification of the target DNA (unpublished observations). Consequently, $200 \mathrm{pg}$ of total DNA (from human tissue) per reaction was used.
Only two of the 99 samples analysed were negative for PCR-mkDNA ( $98 \%$ positivity), so this assay was considered to be the gold standard for determination of the sensitivity of the other PCR assays. The positivity was 81.8\% (81/99) for PCR-ITS1, 41.8\% (33/79) for PCR-g6p and $72.7 \%(72 / 99)$ for PCR-hsp $70-234$ bp. PCR-G6pd was not performed for samples from MT because sufficient DNA was not available. Both samples negative for kDNA were positive for ITS1; only one was positive for hsp70-234 bp and both were negative for g6p (Table II).

Of the 99 samples analysed, 62 were positive for ITS1 and $h s p 70-234 \mathrm{bp}$ and only eight were negative for both targets. A total 19 of samples were positive for ITS1 alone and 10 were positive for $h s p 70-234 \mathrm{bp}$ alone. The agreement between the PCR-ITS1 and PCR-hsp 70-234 bp results was low according to the Kappa index (Kappa $=0.176$, $p$ $=0.071$ ). Combining the two assays (PCR-ITS1 and PCRhsp70-234 bp), 91.9\% (91/99) positivity was achieved.

The sensitivities of PCR-ITS1, PCR- $h s p 70-234$ bp and PCR-G6 $p d$ were $81.4 \%$ (79/97), 73.2\% (71/97) and $41.6 \%(32 / 77)$, respectively, compared with the mkDNA PCR assay.

Whether clinical samples for which amplification products were obtained in every PCR assay could be differentiated at the species level depended on the target, as observed with the cultured strains (Table I). ITS1 PCRRFLP allowed identification of the various Leishmania species in the clinical samples, as follows (number of samples in parentheses): L. braziliensis (58), L. lainsoni (13), L. guyanensis (2), L. naiffi (2), L. shawi (1), L. amazonensis (1) and one sample with a mixed profile between L. lainsoni and L. naiffi (Fig. 2). PCR-G6pd identified samples infected with L. braziliensis (22) vs. non-L. braziliensis (6). Finally, hsp70-234 bp PCR-RFLP identified the following parasite species in the samples: L. braziliensis (50), L. lainsoni (13), L. naiffi (5), L. guyanensis (2), L. shawi (1) and L. amazonensis (1).

Regarding species identification in the 62 samples that were positive for both PCR-ITS1 and PCR-hsp70-234 bp,
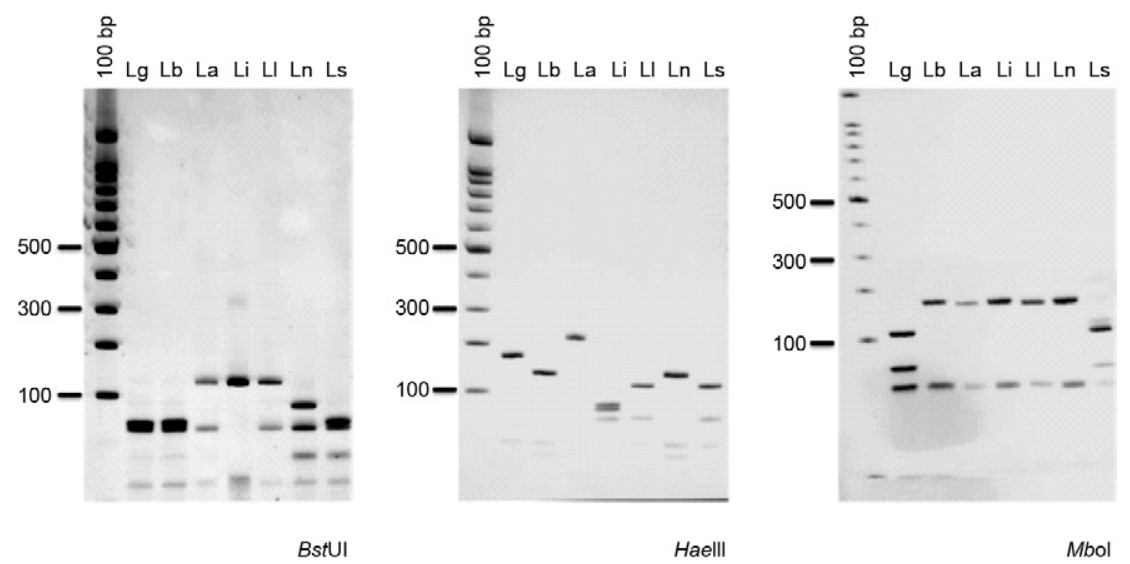

Fig. 3: 234 bp heat-shock protein 70 (hsp70C) polymerase chain reaction-restriction fragment length polymorphism profiles for reference strains of different Leishmania species after digestion of products with BstUI, HaeIII and MboI. Silver-stained $12.5 \%$ polyacrylamide gel (Genephor ${ }^{\circledR}$ ). La: Leishmania amazonensis; Lb: Leishmania braziliensis; Lg: Leishmania guyanensis; Li: Leishmania infantum; Ll: Leishmania lainsoni; Ln: Leishmania naiffi; Ls: Leishmania shawi; 100 bp: molecular weight marker. 
only four samples yielded conflicting results, which are presented below. Twenty-three samples were identified by ITS1 PCR-RFLP, PCR- $h s p 70-234$ bp and PCR-G6pd (Table II). Eighteen samples yielded consistent results. Two samples (RB005 and RB011) yielded conflicting results and were characterised as L. braziliensis by ITS1 PCR-RFLP and PCR-G6pd, but as L. naiffi by hsp70-234 bp PCR-RFLP. One sample (RB053) was characterised as L. naiffi by ITS1 PCR-RFLP, but as L. braziliensis by $h s p 70-234$ bp PCR-RFLP; this sample was positive for PCR-G6pd, which distinguished the subgenus L. (Viannia). Sample RB004 was characterised as L. lainsoni by hsp 70-234 bp PCR-RFLP, but as non-L. braziliensis by PCR-G6pd, whereas the ITS1 PCR-RFLP profile suggested a combination between L. lainsoni and L. naiffi (Fig. 2). These results could indicate either combined infection by L. naiffi and L. lainsoni or a hybrid between these two species, as a combined infection would not explain the hybrid profile observed with MLEE.

Sample RB013 demonstrated a L. guyanensis profile based on ITS1 PCR-RFLP and $h s p 70 \mathrm{C}$ PCR-RFLP, but was positive in all PCR-G6pd assays, thereby precluding identification of this sample as L. braziliensis or non- $L$. braziliensis using this methodology. Strain IOC/L2493 was isolated from sample RB013 and was characterised as L. guyanensis based on all of the markers (Table I). However, after analysis of the L. (Viannia) strains with a battery of microsatellites, strain IOC/L2493 was included in the same cluster as Leishmania panamensis and $L$. shawi (Oddone et al. 2009).

\section{DISCUSSION}

The main objective of this study was to develop a PCR-based method that can be used for diagnosis of CL, to both the infection and allowing identification of the species involved. Previous research indicates that PCRRFLP of a 1400-bp fragment of the Leishmania hsp70 gene can differentiate all of the species circulating in Brazil. Through analysis of 70 strains, the present study validated the previously demonstrated ability of this methodology to discriminate between the various Leishmania species associated with human leishmaniasis in Brazil (da Silva et al. 2010). This portion of the $h s p 70$ gene has also been used in other studies and its potential to distinguish Leishmania species has been discussed. Furthermore, the effectiveness of this target for molecular diagnosis of leishmaniasis has previously been suggested (Garcia et al. 2004, 2007, Fraga et al. 2010).

However, given the large size of the 1400-bp hsp70 fragment, a lower level of success is expected for this target when amplifying small amounts of DNA, such as those obtained from clinical samples. Therefore, new primers were designed to amplify smaller fragments of the Leishmania hsp70 gene. A 234-bp region of the Leishmania hsp70 gene (designated 234-bp PCR-hsp70 in this study) was deemed promising, given its utility for detecting and identifying Leishmania species in clinical samples. The ability of several PCR assays, either following an RFLP approach or not, to discriminate between species was evaluated using a panel of reference strains representing the Leishmania species circulating in Brazil.
Although 120-bp mkDNA PCR-RFLP has been demonstrated to be appropriate for identifying some Leishmania species (Volpini et al. 2004), this approach was not used in the present study because most of the species analysed here belong to the L. (Viannia) subgenus and a conserved region would be not appropriate for distinguishing between closely related species. Furthermore, profile reproducibility and identification of Leishmania species using mkDNA PCR-RFLP could be hindered by variability in the minicircle classes (Brewster \& Barker 2002). ITS1 PCR-RFLP using Sau3AI generated the same profiles as are obtained with HaeIII (E Cupolillo, unpublished observations), which has been used in several studies employing ITS1 PCR-RFLP to diagnose leishmaniasis (Schönian et al. 2003, Nasereddin et al. 2008, Gelanew et al. 2010, Hajjaran et al. 2011). As reported elsewhere, the differences between $L$. braziliensis and L. guyanensis are not easily detected, although there are polymorphisms in the DNA sequences of both species. Therefore, high-resolution gel electrophoresis, which can resolve fragment size differences as small as $4 \mathrm{bp}$, was successfully employed to distinguish between these two species.

A total of 63 strains were used to validate the identification of Leishmania species from different PCRRFLP and PCR-G6pd assays. Notably, the panel of isolates, which represented the diversity of the genus Leishmania, demonstrated the risk of using only reference strains for evaluating the ability of a method to discriminate between species, considering the observed disagreement in the identification of some strains based on the different methods.

Profile reproducibility was satisfactory for ITS1 PCRRFLP, 234-bp $h s p 70$ PCR-RFLP and PCR-G6pd among the assayed strains, though there were a few exceptions. The target associated with the most conflicting results compared with MLEE was 1400-bp hsp70 PCR-RFLP, while 234-bp $h s p 70$ PCR-RFLP corroborated the MLEE identification for all of the evaluated strains. Some strains characterised as L. braziliensis by MLEE presented a non- $L$. braziliensis profile for PCR- $g 6 p$. These strains exhibited an atypical electromorphic profile for the g6PDH enzyme, which was different from the profile observed for the reference strains and the vast majority of strains that were characterised as L. braziliensis $(\mathrm{Cu}-$ polillo et al. 1994, 1995). This result corroborates recent data obtained by our group, which indicate the presence of different alleles for the G6pd gene among $L$. braziliensis strains (unpublished observations). These findings should be considered prior to employing this type of PCR analysis in samples collected from regions where $L$. braziliensis variants have already been described.

Discrepancies among the results related to the identification of Leishmania species were also observed when using clinical samples and the possibility that there were mixed infections among the specimens cannot be ruled out (Camara-Coelho et al. 2011). One explanation for this finding is the differential amplification of each marker, whereby different primers may preferentially amplify DNA from different species.

It has previously been reported that Leishmania strains from various species might exhibit similar pro- 
files, depending on the marker used (Almeida et al. 2011). For the subgenus L. (Viannia), this is expected because the species from this group show high genetic similarity (Cupolillo et al. 1995, 1997, Cupolillo \& Momen 2000), share epitopes (Grimaldi \& MacMahon-Pratt 1996) and exhibit high similarity among partial sequences of certain genes (Croan et al. 1997, Asato et al. 2009, Fraga et al. 2010). Moreover, the mechanisms of genetic recombination have been described for natural populations of Leishmania (Rougeron et al. 2010).

To assess the potential of different targets for molecular diagnosis of leishmaniasis, including species discrimination, the ITS1, G6pd and 234-bp hsp70 regions were employed. The capacity to detect Leishmania spp was compared with the PCR-mkDNA results. Although employing PCR-RFLP mkDNA for species identification appears to be inappropriate (see above), the high sensitivity of this method justifies its use for the molecular diagnosis of leishmaniasis (Pereira et al. 2008, Ampuero et al. 2009, Romero et al. 2009, Kobets et al. 2010, Azmi et al. 2011).

The targets with the highest positive rates were 120 bp mkDNA-PCR, followed by ITS1-PCR, 234-bp $h s p 70$ PCR and $G 6 p d$-PCR. A better performance for mkDNAPCR compared with ITS1-PCR has also been observed in previous studies (Bensoussan et al. 2006, Azmi et al. 2011). This result was expected because primer sets that target sequences with higher copy numbers in the genome will be more sensitive. mkDNA PCR has been considered to represent an excellent alternative for the molecular diagnosis of leishmaniasis because of its high sensitivity, given the approximately 10,000-20,000 minicircles per Leishmania cell (Simpson 1973). Many copies of the ribosomal gene have been observed per Leishmania diploid genome. For example, the presence of 20-40 copies per cell has been reported for L. (Viannia) species (Inga et al. 1998). In at least some Leishmania species, the $h s p 70$ genes are arranged in a single genomic cluster that contains five or six HSP70-I copies followed by one HSP70-II copy (Ramirez et al. 2011), whereas $g 6 p$ is a single-copy gene.

Amplification of the ITS1-PCR and 234-bp hsp70PCR DNA fragments yielded approximately $17 \%$ agreement between the genes. Several studies comparing the use of PCR-based assays for molecular diagnosis of leishmaniasis have demonstrated poor agreement between different methods applied to the same samples (Marfurt et al. 2003, Azmi et al. 2011), but the cause of this disparity has not been established. Discrepant results obtained from different PCR assays can be explained by various factors, such as an unequal distribution of DNA in solution (Chandler 1998). Furthermore, although the primers used in this study were designed to amplify conserved regions, there could be failures in the annealing of the primer sequence with the target DNA, thereby hampering amplification by PCR. Moreover, the presence of a secondary infection with other microorganisms (such as fungi and bacteria) in leishmaniasis lesions is common (Formiga et al. 1986, Edrissian et al. 1990, Vera et al. 2001, Markle \& Makhoul 2004, Bhutto et al. 2009). Some primers may share similarities with DNA sequences of these microorganisms, thus affecting PCR performance.
ITS1 PCR-RFLP and 234-bp $h s p 70$ PCR-RFLP yielded the best results because these methods differentiate between etiological agents at the species level. These findings confirmed the circulation of $L$. braziliensis, L. lainsoni and L. guyanensis in AC (Tojal da Silva et al. 2006) and suggested the presence of $L$. naiffi in this region. Although a strain showing a hybrid profile between $L$. lainsoni and $L$. naiffi had previously been isolated, the latter species had not yet been identified in this region (Tojal da Silva et al. 2006). As expected, only $L$. braziliensis was observed in patients from RJ (de Oliveira-Neto et al. 2000) and the single sample characterised as $L$. naiffi was isolated from a patient who had been infected in the Amazon. L. braziliensis, L. amazonensis, L. shawi and L. lainsoni were found in samples from MT and the first two species have previously been reported in this region (Carvalho et al. 2006). To our knowledge, there are no existing reports of L. shawi and L. lainsoni in MT. Analysing the records of the patient infected with L. lainsoni, it was noted that he was most likely infected in an area where this Leishmania species is circulating (AC) (Tojal da Silva et al. 2006). The patient infected with $L$. shawi acquired the infection in MT, in a region that is north of the state, an area of occurrence of the Amazon Rain Forest. Although the aim of this analysis was not to determine which species are circulating the studied regions (AC, RJ and MT), the results indicate the importance of combining diagnosis with the identification of species for the surveillance of leishmaniasis.

The discrimination of Leishmania species should be addressed to understand the discrepancies among the various markers. The biological species concept cannot be applied to Leishmania and there is currently no agreement regarding the definition of the species boundaries within this genus (Banuls et al. 1999, Schönian et al. 2010b). Therefore, none of the available genotyping systems can currently serve as the gold standard for the identification of a particular species and a combination of different methods is required. However, the use of different protocols is impractical and may be unnecessary when the objective is to combine molecular diagnosis with the identification of an etiological agent or to assist in epidemiological surveillance, prognosis and definition of therapeutic regimens. ITS1 PCR-RFLP delivered promising results and other studies have demonstrated that this assay performs well for the identification of Leishmania species circulating in the Old World (Schönian et al. 2003, Bensoussan et al. 2006, Shahbazi et al. 2008). However, the finding that it was only possible to distinguish between $L$. braziliensis and L. guyanensis via sequencing or highresolution gel electrophoresis limits the utility of ITS1 PCR-RFLP in the areas where these species occur. The 234-bp $h s p 70$ PCR-RFLP assay, which targeted a region of the Leishmania hsp70 gene, combined the ability to detect Leishmania in clinical samples with the ability to discriminate between all of the species circulating in Brazil, which could make this technique particularly useful in areas of sympatry. 


\section{REFERENCES}

Almeida M, Steurer F, Koru O, Herwaldt B, Pieniazek N, da Silva AJ 2011. Identification of Leishmania spp by molecular amplification and DNA sequencing analysis of a fragment of the rRNA internal transcribed spacer 2. J Clin Microbiol 49: 3143-3149.

Ampuero J, Rios AP, Carranza-Tamayo CO, Romero GAS 2009. Genus-specific kinetoplast-DNA PCR and parasite culture for the diagnosis of localized cutaneous leishmaniasis: applications for clinical trials under field conditions in Brazil. Mem Inst Oswaldo Cruz 104: 992-997.

Arévalo J, Ramirez L, Adaui V, Zimic M, Tulliano G, MirandaVerastegui C, Lazo M, Loayza-Muro R, De DS, Maurer A, Chappuis F, Dujardin J, Llanos-Cuentas A 2007. Influence of Leishmania (Viannia) species on the response to antimonial treatment in patients with american tegumentary leishmaniasis. J Infec Dis 195: 1846-1851.

Asato Y, Oshiro M, Myint C, Yamamoto Y, Kato H, Marco J, Mimori T, Gomez E, Hashiguchi Y, Uezato H 2009. Phylogenic analysis of the genus leishmania by cytochrome b gene sequencing. Exp Parasitol 121: 352-361.

Aviles H, Belli A, Armijos R, Monroy F, Harris E 1999. PCR detection and identification of Leishmania parasites in clinical specimens in Ecuador: a comparison with classical diagnostic methods. J Parasitol 85: 181-187.

Azeredo-Coutinho R, Conceição-Silva F, Schubach A, Cupolillo E, Quintella L, Madeira M, Pacheco R, Valete-Rosalino C, Mendonça S 2007. First report of diffuse cutaneous leishmaniasis and Leishmania amazonensis infection in Rio de Janeiro state, Brazil. Trans R Soc Trop Med Hyg 101: 735-737.

Azmi K, Nasereddin A, Ereqat S, Schnur L, Schonian G, Abdeen Z 2011. Methods incorporating a polymerase chain reaction and restriction fragment length polymorphism and their use as a 'gold standard' in diagnosing Old World cutaneous leishmaniasis. $D i$ agn Microbiol Infect Dis 71: 151-155.

Azpurua J, De LCD, Valderama A, Windsor D 2010. Lutzomyia sand fly diversity and rates of infection by Wolbachia and an exotic Leishmania species on Barro Colorado Island, Panama. PLoS Negl Trop Dis 4: e627.

Banuls A, Hide M, Tibayrenc M 1999. Molecular epidemiology and evolutionary genetics of Leishmania parasites. Int J Parasitol 29: 1137-1147.

Bensoussan E, Nasereddin A, Jonas F, Schnur L, Jaffe C 2006. Comparison of PCR assays for diagnosis of cutaneous leishmaniasis. J Clin Microbiol 44: 1435-1439.

Bhutto A, Soomro F, Baloch J, Matsumoto J, Uezato H, Hashiguchi Y, Katakura K 2009. Cutaneous leishmaniasis caused by Leishmania (L.) major infection in Sindh province, Pakistan. Acta Trop 111: 295-298.

Brewster S, Barker D 2002. Analysis of minicircle classes in Leishmania (Viannia) species. Trans R Soc Trop Med Hyg 96: S55-S63.

Camara-Coelho LI, Paes M, Guerra JA, Barbosa MG, Coelho C, Lima B, Brito ME, Brandão-Filho S 2011. Characterization of Leishmania spp causing cutaneous leishmaniasis in Manaus, Amazonas, Brazil. Parasitol Res 108: 671-677.

Carvalho M de L, de Andrade AS, Fontes CJ, Hueb M, de Oliveira Silva S, Melo MN 2006. Leishmania (Viannia) braziliensis is the prevalent species infecting patients with tegumentary leishmaniasis from Mato Grosso State, Brazil. Acta Trop 98: 277-285.

Castilho T, Shaw J, Floeter-Winter L 2003. New PCR assay using glucose-6-phosphate dehydrogenase for identification of Leishmania species. J Clin Microbiol 41: 540-546.
Chandler DP 1998. Redefining relativity: quantitative PCR at low template concentrations for industrial and environmental microbiology. J Ind Microbiol Biotechnol 21: 128-140.

Croan D, Morrison D, Ellis J 1997. Evolution of the genus Leishmania revealed by comparison of DNA and rna polymerase gene sequences. Mol Biochem Parasitol 89: 149-159.

Cupolillo E, Grimaldi G, Momen H 1994. General classification of New World Leishmania using numerical zymotaxonomy. Am J Trop Med Hyg 50: 296-311.

Cupolillo E, Grimaldi GJ, Momen H 1997. Genetic diversity among Leishmania (Viannia) parasites. Ann Trop Med Parasitol 91: 617-626.

Cupolillo E, Grimaldi G, Momen H, Beverley S 1995. Intergenic region typing (IRT) - a rapid molecular approach to the characterization and evolution of Leishmania. Mol Biochem Parasitol 73: 145-155.

Cupolillo E, Momen H 2000. Speculations on the origin and evolution of the genus Leishmania. Mem Inst Oswaldo Cruz 95: 583-588.

da Silva LA, de Sousa CS, da Graça GC, Porrozzi R, Cupolillo E 2010. Sequence analysis and PCR-RFLP profiling of the $h s p 70$ gene as a valuable tool for identifying Leishmania species associated with human leishmaniasis in Brazil. Infect Genet Evol 10: 77-83.

de Oliveira-Neto M, Mattos M, Perez M, Da-Cruz A, Fernandes O, Moreira J, Gonçalves-Costa S, Brahin L, Menezes C, Pirmez C 2000. American tegumentary leishmaniasis (ATL) in Rio de Janeiro state, Brazil: main clinical and epidemiologic characteristics. Int J Dermatol 39: 506-514.

Desjeux P 2004. Leishmaniasis: current situation and new perspectives. Comp Immunol Microbiol Infect Dis 27: 305-318.

Edrissian G, Mohammadi M, Kanani A, Afshar A, Hafezi R, Ghorbani M, Gharagozloo A 1990. Bacterial infections in suspected cutaneous leishmaniasis lesions. Bull World Health Organ 68: 473-477.

Formiga LCD, Assis ACB, Rangel LBA, Camello TCF, Suassuna I, Netto EM, Marsden PD 1986. Isolamento de Corynebacterium diphtheriae de úlceras cutâneo-mucosas por Leishmania. Rev Bras Patol Clin 22: 202-204.

Fraga J, Montavalo A, Doncker S, Dujardin J, Auwera G 2010. Phylogeny of Leishmania species based on the heat-shock protein 70 gene. Infect Genet Evol 10: 238-245.

Garcia A, Parrado R, De Doncker S, Bermudez H, Dujardin J 2007. American tegumentary leishmaniasis: direct species identification of Leishmania in non-invasive clinical samples. Trans $R$ Soc Trop Med Hyg 101: 368-371.

Garcia L, Kindt A, Bermudez H, Llanos-Cuentas A, De Doncker S, Arevalo J, Tintaya KWQ, Dujardin JC 2004. Culture-independent species typing of neotropical Leishmania for clinical validation of a PCR-based assay targeting heat shock protein 70 genes. J Clin Microbiol 42: 2294-2297.

Gelanew T, Amogne W, Abebe T, Kuhls K, Hailu A, Schönian G 2010. A clinical isolate of Leishmania donovani with ITS1 sequence polymorphism as a cause of para-kala-azar dermal leishmaniasis in an ethiopian human immunodeficiency virus-positive patient on highly active antiretroviral therapy. Br J Dermatol 163: 870-874.

Goto H, Lindoso JA 2010. Current diagnosis and treatment of cutaneous and mucocutaneous leishmaniasis. Expert Rev Anti Infect Ther 8: 419-433.

Grimaldi Jr G, McMahon-Pratt D 1996. Monoclonal antibodies for the identification of New World Leishmania species. Mem Inst Oswaldo Cruz 91: 37-42.

Guerra J, Prestes S, Silveira H, Coelho L, Gama P, Moura A, Amato V, Barbosa M, Ferreira L 2011. Mucosal leishmaniasis caused by 
Leishmania (Viannia) braziliensis and Leishmania (Viannia) guyanensis in the Brazilian Amazon. PLoS Negl Trop Dis 85: e980.

Hajjaran H, Vasigheh F, Mohebali M, Rezaei S, Mamishi S, Charedar S 2011. Direct diagnosis of Leishmania species on serosity materials punctured from cutaneous leishmaniasis patients using PCR-RFLP. J Clin Lab Anal 25: 20-24.

Herwaldt B 1999. Leishmaniasis. Lancet 2354: 1191-1199.

Inga R, De Doncker S, Gomez J, Lopez M, Garcia R, Le Ray D, Arevalo J, Dujardin JC 1998. Relation between variation in copy number of ribosomal RNA encoding genes and size of harbouring chromosomes in Leishmania of subgenus Viannia. Mol Biochem Parasitol 1: 219-228.

Kobets T, Badalová J, Grekov I, Havelková H, Svobodová M, Lipoldová M 2010. Leishmania parasite detection and quantification using PCR-ELISA. Nat Protoc 5: 1074-1080.

Marfurt J, Niederwiese I, Divine M, Beck H, Felger I 2003. Diagnostic genotyping of old and new world Leishmania species by PCR-RFLP. Diag Microbiol Infect Dis 46: 115-124.

Markle W, Makhoul K 2004. Cutaneous leishmaniasis: recognition and treatment. Am Fam Physician 69: 1455-1460.

Montalvo A, Fraga J, Monzote L, Montano I, De Doncker S, Dujardin J, Van Der Auwera G 2010. Heat-shock protein 70 PCR-RFLP: a universal simple tool for Leishmania species discrimination in the New and Old World. Parasitology 137: 1159-1168.

Nasereddin A, Bensoussan-Hermano E, Schönian G, Baneth G, Jaffe C 2008. Molecular diagnosis of Old World cutaneous leishmaniasis and species identification by use of a reverse line blot hybridization assay. J Clin Microbiol 46: 2848-2855.

Oddone R, Schweynoch C, Schönian G, de Sousa C, Cupolillo E, Espinosa D, Arevalo J, Noyes H, Mauricio I, Kuhls K 2009. Development of a multilocus microsatellite typing approach for discriminating strains of Leishmania (Viannia) species. J Clin Microbiol 47: 2818-2825.

Pereira EFA, Thomaz-Soccol V, Lima H, Thomaz-Soccol A, de Castro E, Mulinari-Brenner F, Queiroz-Telles F, Luz E 2008. Molecular diagnosis of leishmaniasis in the Paraná state of southern Brazil. Exp Dermatol 17: 1024-1030.

Ramirez CA, Requena JM, Puerta CJ 2011. Identification of the HSP70II gene in Leishmania braziliensis HSP70 locus: genomic organization and UTRs characterization. Parasit Vectors 26: 166.

Reithinger R, Dujardin J 2007. Molecular diagnosis of leishmaniasis: current status and future applications. J Clin Microbiol 45: 21-25.

Reithinger R, Dujardin J, Louzir H, Pirmez C, Alexander B, Simon B 2007. Cutaneous leishmaniasis. Lancet Infect Dis 7: 581-596.

Rioux J, Lanotte G, Serres E, Pratlong F, Bastien P, Perieres J 1990. Taxonomy of Leishmania. Use of isoenzyme: suggestion for a new classification. Ann Parasitol Hum Comp 65: 111-125.

Romero G, Guerra M, Paes M, Macedo VO 2001. Comparison of cutaneous leishmaniasis due to Leishmania (Viannia) braziliensis and L.(V.) guyanensis in Brazil: therapeutic response to meglumine antimoniate. Am J Trop Med Hyg 65: 456-465.
Romero G, Noronha E, Pirmez C, Pires F, Fernandes O, Nehme N, Cupolillo E, Firoozmand L, da Graça G, Volpini A, Santos S, Romanha A 2009. Sensitivity and reproducibility of a per assay for Leishmania detection using skin biopsy imprints on filter paper. Acta Trop 109: 74-77.

Ross R 1903. Futher notes on leishman's. BMJ 11: 1401.

Rougeron V, De Meeûs T, Kako Ouraga S, Hide M, Bañuls A 2010. Everything you always wanted to know about sex (but were afraid to ask) in Leishmania after two decades of laboratory and field analyses. PLoS Pathog 19: e1001004.

Schönian G, Kuhls K, Mauricio IL 2010a. Molecular approaches for a better understanding of the epidemiology and population genetics of Leishmania. Parasitology 16: 1-21.

Schönian G, Kuhls K, Mauricio IL 2011. Molecular approaches for a better understanding of the epidemiology and population genetics of Leishmania. Parasitology 138: 405-425.

Schönian G, Mauricio I, Cupolillo E 2010b. Is it time to revise the nomenclature of Leishmania? Trends Parasitol 26: 466-469.

Schönian G, Nasereddin A, Dinse N, Schweynoch C, Schallig H, Presber W, Jaffe C 2003. PCR diagnosis and characterization of Leishmania in local and imported clinical samples. Diag Microbiol Infect Dis 47: 349-358.

Shahbazi F, Shahabi S, Kazemi B, Mohebali M, Abadi A, Zare Z 2008. Evaluation of PCR assay in diagnosis and identification of cutaneous leishmaniasis: a comparison with the parasitological methods. Parasitol Res 103: 1159-1162.

Simpson L 1973. Structure and function of kinetoplast DNA. J Protozool 20: 2-8.

Tojal da Silva A, Cupolillo E, Volpini A, Almeida R, Romero G 2006. Species diversity causing human cutaneous leishmaniasis in Rio Branco, state of Acre, Brazil. Trop Med Int Health 11: 1388-1398.

van Thiel P, Leenstra T, de Vries H, van der Sluis A, van Gool T, Krull A, van Vugt M, de Vries P, Zeegelaar J, Bart A, van der Meide W, Schallig H, Faber W, Kager P 2010. Cutaneous leishmaniasis (Leishmania major infection) in Dutch troops deployed in northern Afghanistan: epidemiology, clinical aspects and treatment. Am J Trop Med Hyg 83: 1295-1300.

Vera L, Santos J, Macêdo V, de Magalhães A, Ciuffo I, Santos C 2001. Evaluation of secondary bacterial infection's influence on the course of cutaneous leishmaniasis in Corte de Pedra, Bahia. Rev Soc Bras Med Trop 34: 233-237.

Volpini A, Passos V, Oliveira G, Romanha A 2004. PCR-RFLP to identify Leishmania (Viannia) braziliensis and L. (Leishmania) amazonensis causing american cutaneous leishmaniasis. Acta Tropica 90: 31-37.

Weigle K, Saravia N, Dedavalos M, Moreno L, Dalessandro A 1986. Leishmania braziliensis from the pacific coast region of Colombia foci of transmission, clinical spectrum and isoenzyme phenotypes. Am J Trop Med Hyg 35: 722-731.

Wilson M, Young B, Andersen K, Weinstock J, Metwali A, Ali K, Donelson J 1995. A recombinant Leishmania chagasi antigen that stimulates cellular immune-responses in infected mice. Infect Immun 63: 2062-2069. 